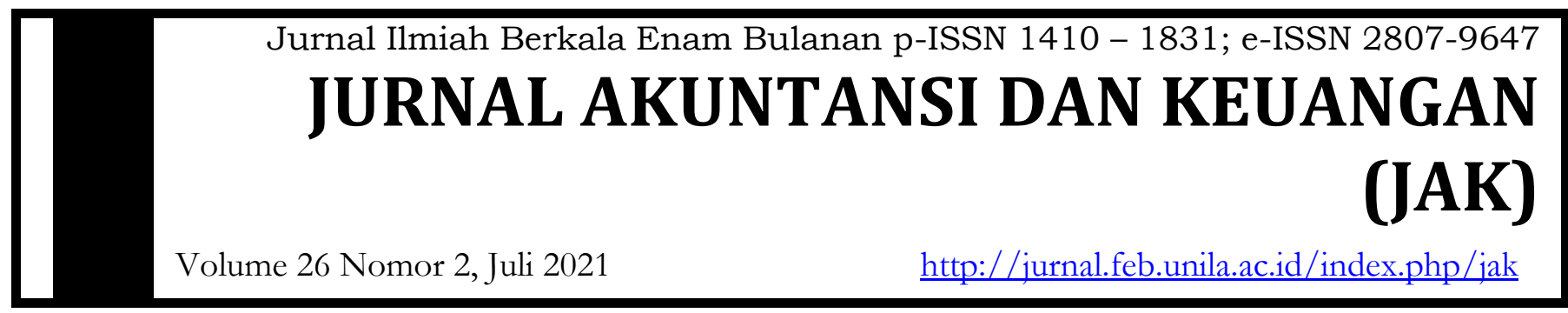

\title{
PENGARUH SISTEM PENGENDALIAN MANAJEMEN TERHADAP KINERJA PENGADILAN DI MASA WABAH COVID-19
}

\author{
Annisa Mulia Aghsya ${ }^{1}$, Ratna Septiyanti², Yenni Agustina ${ }^{3}$, Usep Syaipudin ${ }^{4}$ \\ ${ }^{1}$ Fakultas Ekonomi dan Bisnis, Universitas Lampung \\ ${ }^{2}$ Fakultas Ekonomi dan Bisnis, Universitas Lampung \\ 3 Fakultas Ekonomi dan Bisnis, Universitas Lampung \\ 4 Fakultas Ekonomi dan Bisnis, Universitas Lampung
}

\section{Informasi Naskah}

Update Naskah:

Dikumpulkan: 4 Juni 2021

Diterima: 5 Juli 2021

Terbit/Dicetak: 30 Juli 2021

\section{Keywords:}

Management Control Systems, Organizational Performance

\section{Abstract}

This research aims to know the effect of management control system towards organizational performance in Pengadilan Negeri Tanjung Karang class 1A during covid-19. This research is a quantitative study using a survey method with data collection techniques using a questionnaire which is measured by using the SPSS version 26 program. The population in this study were all employees of Pengadilan Negeri Tanjung Karang class IA, sampling using saturated sampling techniques namely all employees of Pengadilan Negeri Tanjung Karang class IA so that a total sample of 100 was obtained. The data analysis technique used the correlation test. The results of this study indicate that the management control system has a positive and significant effect on organizational performance during the Covid19. With a determination coefficient of 0.728 , the influence of management control system towards the performance of Pengadilan Negeri Tanjung Karang class IA during the Covid-19 was $72.8 \%$, while the remaining $27.2 \%$ was influenced by other factors not examined in this study. 


\section{A. PENDAHULUAN}

Hingga saat ini jumlah pasien positif Covid-19 terus mengalami peningkatan. Dalam hal ini untuk mengatasi peningkatan pasien virus corona pemerintah Indonesia mengeluarkan kebijakan untuk menerapkan sistem pembatasan sosial (social distancing) dan penjagaan jarak (physical distancing). Dengan adanya penerapan sistem ini telah memberikan dampak tersendiri bagi kehidupan masyarakat, baik secara sosial maupun ekonomi. Adanya pembatasan sosial telah membatasi banyak bidang dalam menjalankan tugas dan fungsinya dengan semestinya sehingga menyebabkan kerugian yang cukup besar.

Dampak penerapan pembatasan sosial ini dirasakan oleh berbagai sektor, salah satunya Instansi Pengadilan Negeri. Instansi pengadilan adalah badan resmi yang melaksanakan sistem peradilan berupa pemeriksaan, kegiatan mengadili, dan memutus suatu perkara (Widodo, 2014). Pelaksanaan kerja dalam sistem Peradilan di Pengadilan Negeri berbentuk sebuah forum publik yang resmi dan dilakukan berdasarkan hukum acara yang berlaku di Indonesia. Kondisi pandemi Covid-19 pada saat ini mempengaruhi kinerja organisasi khususnya di bidang pelayanan sektor publik yang mengharuskan pemerintah menerapkan kebijakan Work From Home (WFH) bagi para Aparatur Sipil Negara (ASN) yang berpengaruh terhadap kinerja pekerja sektor publik. Adanya larangan berkegiatan dalam suatu forum seperti biasanya telah banyak mengubah sistem kerja yang telah ada pada Pengadilan Negeri Tanjung Karang Kelas IA sebelumnya. Dengan diberlakukannya Work From Home (WFH) bagi pegawai-pegawai yang bergerak dalam pelayanan publik menyebabkan pelayanan publik menjadi terhambat karena pada akhirnya beberapa bidang pelayanan tidak dapat melayani masyarakat secara langsung melalaikan dengan memberikan pelayanan melalui sistem online.

Oleh karena itu peran sistem pengendalian manajemen sangat penting untuk beradaptasi agar tetap menjalankan fungsi dan tujuan organisasi walaupun dalam kondisi pandemi Covid-19. Sistem pengendalian manajemen adalah sistem yang digunakan oleh manajemen untuk mempengaruhi para anggota organisasi agar mengimplementasikan strategi-strategi organisasi secara efisien dan efektif dalam rangka mencapai tujuan organisasi. Sumarsan (2013), menjelaskan bahwa sistem pengendalian manajemen merupakan suatu rangkaian tindakan dan aktifitas yang terjadi pada seluruh kegiatan organisasi dan berjalan secara terus menerus. Pengendalian manajemen bukan merupakan suatu sistem terpisah dalam organisasi melainkan sebagai bagian penting dari setiap sistem manajemen untuk mengatur dan mengarahkan kegiatan. Menurut Terry yang dikutip oleh Herujito (2006), menyebutkan bahwa fungsi manajemen terdiri dari empat fungsi yang disingkat dengan POAC yaitu planning (merencanakan), organizing (menyusun), actuating (pelaksanaan), dan controlling (mengawasi). Sistem pengendalian manajemen yang baik sangat dibutuhkan dalam tonggak pelaksanaan kegiatan selama masa pandemi berlangsung. Dengan menerapkan sistem pengendalian manajemen yang terorganisir dengan baik diharapkan instansi-instansi mampu mempertahankan kinerja yang sesuai dengan tugas dan fungsinya walaupun dihadapkan dengan situasi pandemi.

Terdapat penelitian terdahulu yang telah meneliti pada penelitian Rofikotul (2017) dalam penelitiannya menjelaskan bahwa sistem pengendalian manajemen memiliki peran besar bagi peningkatan kinerja organisasi. Studi yang telah ada (Antony, 1966; Miller \& Friesen, 1982; Govindarajan, 1988; Simon, 1990; Fisher, 1998; Syaruddin, 2001; Tugiman, 2002; Wasito dan Ghozali, 2002) menemukan efektifitas pengendalian manajemen yang digunakan dalam organisasi berpengaruh secara signifikan terhadap peningkatan kinerja perusahaan. Hal ini juga sejalan dengan hasil penelitian Gani (2013) yang menunjukkan bahwa Sistem Pengendalian Manajemen berpengaruh positif terhadap Kinerja Perusahaan.

\section{B. LANDASAN TEORI DAN PENGEMBANGAN HIPOTESIS}

\section{Teori Kontingensi}


Dasar dari teori ini adalah bahwa merupakan tugas pemimpin untuk membantu anggotanya dalam mencapai tujuan mereka dan untuk memberi arah dan dukungan atau keduanya yang dibutuhkan untuk menjamin tujuan mereka sesuai dengan tujuan kelompok atau organisasi secara keseluruhan. Jika dikaitkan dengan teori kontingensi kepemimpinan, sebagaimana yang disimpulkan oleh Fiedler, bahwa pemimpin yang mempunyai motivasi kerja umumnya menunjukkan kinerja terbaik dalam kondisi yang paling baik, baik dalam kondisi dimana kekuasaan, kontrol dan pengaruhnya sangat tinggi, ataupun dalam kondisi yang tak menentu, dimana kontrol, kekuasaan dan pengaruh yang rendah. Pemimpin yang mempunyai motivasi hubungan cenderung menunjukkan kondisi terbaik ketika dia mempunyai kekuasaan, kontrol dan pengaruh yang cukup baik dan efektifitas pengendalian manajemen yang digunakan dalam organisasi berpengaruh secara signifikan terhadap peningkatan kinerja perusahaan. Ini artinya sistem pengendalian manajemen memiliki peran besar bagi peningkatan kinerja organisasi.

\section{Sektor Publik}

Sektor publik adalah sebuah organisasi entitas ekonomi negara untuk menjalankan tugas sebagai pengendali masyarakat menuju kesejahteraan. Kendali tersebut berupa penyediaan layanan yang bermanfaat untuk publik. Secara kelembagaan, wilayah publik meliputi organisasi non laba pemerintahan dan bentuk organisasi non laba nonpemerintah (Renyowijoyo, 2012). Pada dasarnya sektor publik berorientasi pada pemenuhan kebutuhan publik atau masyarakat. Pengadilan merupakan salah satu organisasi sektor publik nonlaba pemerintahan yang berperan untuk memberikan pelayanan kepada masyarakat terkait dengan layanan hukum dalam rangka memenuhi kebutuhan dan hak publik bagi masyarakat.

\section{Sistem Pengendalian Manajemen}

Terkait dengan kondisi saat ini sedang terjadi pandemi Covid-19 dibutuhkan manajemen yang tepat dalam menangani kondisi pandemi agar fungsi organisasi dapat terus berjalan, untuk itu sistem pengendalian manajemen sangat penting perannya agar fungsi dan tujuan organisasi dapat berjalan dengan baik dan dapat bersinergi dalam aturan yang diterapkan oleh pemerintah. Penerapan sistem pembatasan sosial yang kini diterapkan oleh pemerintah yang berpengaruh terhadap kinerja pekerja sektor publik yang menyebabkan aktifitas pelayanan publik menjadi terhambat. Dalam hal ini Pengadilan sebagai penyelenggara pelayanan publik kemudian membuat inovasi-inovasi dalam memberikan pelayanan agar pelayanan tidak terhambat seperti memberikan pelayanan melalui sistem online untuk mencapai kinerja organisasi yang optimal dalam situasi pandemi Covid-19.

\section{Kinerja Organisasi}

Kinerja merupakan hasil yang diperoleh oleh suatu organisasi baik organisasi tersebut bersifat profit oriented dan nonprofit oriented yang dihasilkan dalam satu periode waktu. Sistem pengendalian manajemen menentukan kualitas kerja dari suatu organisasi. Kinerja organisasi merupakan sesuatu yang dihasilkan oleh suatu organisasi dalam periode tertentu dengan mengacu kepada standar yang ditetapkan. Kinerja organisasi merupakan hal penting yang harus dicapai oleh setiap organisasi karena merupakan kemampuan organisasi dalam mengelola dan mengalokasikan sumber daya yang dimilikinya (Verbeeten, 2007). Apabila sistem pengendalian manajemen pada Pengadilan Negeri berjalan buruk, maka akan buruk pula kualitas kerjanya. Adanya sistem pengendalian manajemen mampu menjadi pengarah anggota organisasi agar dalam satu tujuan dan tindakan yang sesuai dengan tujuan organisasi tersebut. Penggunaan sistem pengendalian manajemen yang lebih komprehensif dan informatif akan dapat meningkatkan kinerja organisasi (Peljhan et al, 2008).

\section{METODE PENELITIAN Populasi dan Sampel}


Populasi riset ini adalah Pengadilan Negeri Tanjung Karang kelas IA yang berlokasi di Kota Bandar Lampung. Pengambilan sampel pada penelitian ini adalah seluruh populasi pegawai di kantor Pengadilan Negeri Tanjung Karang kelas IA. Metode yang digunakan dalam penelitian ini adalah pengumpulan data dengan menggunakan kuesioner.

Tabel 1 Distribusi Kuesioner Penelitian

\begin{tabular}{lll}
\hline No. & \multicolumn{1}{c}{ Keterangan } & Jumlah Responden \\
\hline 1. & Jumlah kuesioner yang disebar & 103 \\
2. & Jumlah kuesioner yang kembali & 100 \\
3. & Jumlah kuesioner yang dapat diolah & 100 \\
\hline \multicolumn{3}{c}{ Sumber: Data Kuesioner yang telah diolah, 2020. }
\end{tabular}

Dari penyebaran kuesioner yang dilakukan oleh peneliti dapat diketahui bahwa jumlah kuesioner yang disebar adalah sebanyak 103 kuesioner. Kuesioner yang kembali berjumlah 100 kuesioner sedangkan terdapat kuesioner yang tidak dikumpulkan kembali oleh responden yakni berjumlah 3 kuesioner yang tidak sehingga kuesioner tersebut tidak dapat digunakan untuk menjadi data penelitian. Dengan demikian jumlah kuesioner yang dapat diolah berjumlah 100 kuesioner.

\section{Karakteristik Responden}

Profil responden yang menjadi sampel dalam penelitian ini dibagi berdasarkan jenis kelamin, usia, dan pendidikan terakhir sebagai pegawai. Secara rinci tabulasi responden disajikan dalam tabel berikut:

Tabel 2 Jenis Kelamin Responden

\begin{tabular}{lll}
\hline Jenis Kelamin & Jumlah & Persentase \\
\hline Pria & 54 & $54 \%$ \\
Wanita & 46 & $46 \%$ \\
Total & $\mathbf{1 0 0}$ & $\mathbf{1 0 0 \%}$ \\
\hline
\end{tabular}

Sumber: Data Kuesioner yang telah diolah, 2020.

Dari penyebaran kuesioner yang dilakukan oleh peneliti dapat diketahui bahwa jumlah responden pria adalah sebanyak 55 orang. Sementara jumlah responden wanita adalah sebanyak 48 orang.

Tabel 3 Usia Responden

\begin{tabular}{lll}
\hline Usia & Jumlah & Persentase \\
\hline$\leq 25$ Tahun & 0 & $0 \%$ \\
26 - 35 Tahun & 32 & $32 \%$ \\
36 - 45 Tahun & 37 & $37 \%$ \\
$\geq$ 45 Tahun & 29 & $29 \%$ \\
Total & $\mathbf{1 0 0}$ & $\mathbf{1 0 0 \%}$ \\
\hline
\end{tabular}

Sumber: Data Kuesioner yang telah diolah, 2020.

Berdasarkan tabel 3, bahwa karakteristik responden berdasarkan usia tidak ada responden yang berusia kurang dari 25 tahun. Responden dengan rentang umur dari 26 tahun sampai dengan 35 tahun adalah sebanyak 29 orang. Responden dengan rentang umur dari 36 tahun sampai dengan 45 tahun berjumlah 32 orang. Sementara jumlah responden dengan rentang umur dari 46 tahun sampai dengan 55 tahun berjumlah 37 orang.

Tabel 4 Pendidikan Terakhir Responden

\begin{tabular}{lcc}
\hline Pendidikan & Jumlah & Persentase \\
\hline SMA & 6 & $6 \%$ \\
Diploma & 3 & $3 \%$ \\
Sarjana & 47 & $47 \%$ \\
S2 & 44 & $44 \%$ \\
Total & $\mathbf{1 0 0}$ & $\mathbf{1 0 0 \%}$ \\
\hline
\end{tabular}


Berdasarkan tabel 4, bahwa responden yang memiliki pendidikan terakhir SMA adalah sebanyak 6 orang. Responden yang pendidikan terakhirnya diploma berjumlah 3 orang. Sementara responden yang pendidikan terakhirnya sarjana adalah 47 orang. Dan responden yang pendidikan terakhirnya S2 berjumlah 44 orang. Semua informasi yang disajikan dalam demografi responden tersebut diperoleh dari hasil distribusi kuesioner yang merupakan faktor yang dapat menentukan sikap dalam memberikan penilaian terhadap setiap item pertanyaan dalam kuesioner yang dikarenakan oleh pengetahuan, pandangan, pengalaman dan keyakinan yang berbeda, sehingga akan memengaruhi penilaiannya.

\section{Jenis dan Sumber Data}

Penelitian ini dilakukan dengan metode survei untuk memperoleh opini responden. Data dalam penelitian ini diperoleh dengan cara menyerahkan kuesioner secara kolektif kepada petugas yang berwenang dikarenakan Pengadilan Negeri Tanjung Karang Kelas IA telah menerapkan pelayanan terpadu satu pintu (PTSP) yang tidak memperkenankan pihak-pihak luar untuk masuk ke dalam wilayah kerja pegawai Pengadilan Negeri Tanjung Karang Kelas IA dan selanjutnya memintanya kembali apabila responden telah memberikan jawaban pada tanggal yang dijanjikan.

\section{Definisi Operasional Variabel \\ Variabel Dependen (Y)}

Variabel Dependen yang digunakan adalah Kinerja Organisasi. Kinerja organisasi adalah merupakan hasil kerja yang secara kualitas dan kuantitas dapat dicapai oleh seorang pegawai dalam melaksanakan tugas sesuai tanggung jawab yang diberikan kepadanya (Koesmono, 2005). Kinerja organisasi dalam penelitian ini menggunakan instrumen yang dikembangkan peneliti Verbeeten (2007) yang diukur menggunakan lima indikator yaitu jumlah layanan yang tersedia, efisiensi operasi, kepuasan, kualitas layanan, dan pengaruh hasil layanan dengan menggunakan skala Likert 1 sampai 5 dan pada itemitem pertanyaan dalam kuesioner dalam penelitian ini disesuaikan dengan kondisi di Pengadilan dan kondisi wabah Covid-19 saat ini.

\section{Variabel Independen $(\mathrm{X})$}

Variabel independen yang digunakan adalah Sistem Pengendalian Manajemen. Pengendalian manajemen sebagai perolehan dan penggunaan informasi untuk membantu mengkoordinasikan proses pembuatan perencanaan dan pembuatan keputusan melalui organisasi dan untuk memandu perilaku karyawan. Variabel Sistem Pengendalian Manajemen dalam penelitian ini terdiri dari delapan indikator yaitu struktur organisasi yang menggambarkan tugas, wewenang dan tanggung jawab secara jelas, tata cara pelaksanaan dan waktu pelaksanaan, perencanaan anggaran pelaksanaan, peninjauan rencana kerja dan anggaran, peninjauan prosedur pelaksanaan, mempublikasikan pedoman kerja, pengecekan protokol kesehatan terhadap pegawai, dan penyusunan laporan periodik di masa wabah Covid-19 yang telah di sesuaikan dengan kondisi di Pengadilan dan kondisi wabah COVID-19.

\section{Teknik Pengumpulan Data}

Pengumpulan data pada penelitian dilakukan dengan metode pengumpulan data dengan menggunakan kuesioner. Dalam penelitian ini sumber data di peroleh dari respon individu dan teknik pengumpulan data dengan kuesioner. Pertanyaan dalam kuesioner untuk konstruk penelitian diukur dengan skala interval, yaitu skala yang bernilai klasifikasi, order (ada urutannya), dan berjarak (Hartono, 2007).

Data dalam penelitian ini diperoleh dengan cara menyerahkan kuesioner secara kolektif kepada petugas yang berwenang dikarenakan Pengadilan Negeri Tanjung Karang Kelas IA telah menerapkan pelayanan terpadu satu pintu (PTSP) yang tidak memperkenankan pihak-pihak luar untuk masuk ke dalam wilayah kerja pegawai Pengadilan Negeri Tanjung Karang Kelas IA dan selanjutnya memintanya kembali 
apabila responden telah memberikan jawaban pada tanggal yang dijanjikan.

Pertanyaan-pertanyaan pada angket tertutup dibuat dengan Likert 1-5 dengan menggunakan pertanyaan dengan menggunakan pertanyaan berskala (scaling question). Skala Likert digunakan untuk mengukur sikap, pendapat, dan persepsi seseorang atau kelompok tentang fenomena sosial yang telah ditetapkan secara spesifikasi oleh peneliti yang selanjutnya disebut sebagai variabel penelitian. Jawaban setiap item instrument yang menggunakan skala Likert mempunyai gradasi dari sangat positif sampai sangat negatif.

\section{Koefisien Determinasi $\left(\mathbf{R}^{2}\right)$}

Koefisien determinasi $\mathrm{R}^{2}$ pada intinya mengukur seberapa jauh kemampuan model dalam menerangkan variabel - variabel dependen (Ghozali, 2016). Nilai koefisien determinasi adalah nol dan satu. Nilai $\mathrm{R}^{2}$ yang kecil berarti kemampuan variabel-variabel independen dalam menjelaskan variasi variabel dependen sangat terbatas. Nilai yang mendekati satu berarti variabel-variabel independen memberikan hampir semua informasi yang dibutuhkan untuk memprediksi variasi variabel dependen (Ghozali, 2016). Secara sistematis model analisis regresi sederhana dapat digambarkan sebagai berikut:

$$
Y=a+b X+\varepsilon
$$

Keterangan:

$\mathrm{X}=$ sistem pengendalian manajemen $\mathrm{Y}=$

kinerja Pengadilan

$$
\begin{array}{ll}
\mathrm{a} & =\text { konstanta } \\
\mathrm{b} & =\text { koefisien korelasi } \\
\varepsilon & =\text { variabel lain yang tidak diteliti }
\end{array}
$$

\section{ANALISIS DAN PEMBAHASAN}

\section{Uji Kualitas Data \\ Uji Validitas}

Uji Validitas digunakan untuk mengukur sah atau valid tidaknya suatu kuesioner dalam mengukur suatu konstruk, dan apakah dimensi-dimensi yang diukur secara sungguh-sungguh mampu menjadi itemitem dalam pengukuran (Ghozali, 2013). Pengujian validitas dalam penelitian ini menggunakan alat analisis product moment serta perhitungannya menggunakan SPSS versi 26.

\begin{tabular}{cccc}
\multicolumn{4}{c}{ Tabel 5 Hasil Uji Validitas Sistem Pengendalian Manajemen $(\mathbf{X})$} \\
\hline Pernyataan & r hitung & r tabel 5\% (100) & Keterangan \\
\hline X.1 & 0,613 & 0,196 & Valid \\
X.2 & 0,706 & 0,196 & Valid \\
X.3 & 0,599 & 0,196 & Valid \\
X.4 & 0,577 & 0,196 & Valid \\
X.5 & 0,583 & 0,196 & Valid \\
X.6 & 0,611 & 0,196 & Valid \\
X.7 & 0,603 & 0,196 & Valid \\
X.8 & 0,620 & 0,196 & Valid \\
\hline
\end{tabular}

Tabel 6 Hasil Uji Validitas Kinerja Pengadilan (Y)

\begin{tabular}{cccc}
\hline Pernyataan & r hitung & r tabel 5\% (100) & Keterangan \\
\hline Y.1 & 0,782 & 0,196 & Valid \\
Y.2 & 0,676 & 0,196 & Valid \\
Y.3 & 0,643 & 0,196 & Valid \\
Y.4 & 0,672 & 0,196 & Valid \\
Y.5 & 0,692 & 0,196 & Valid \\
\hline
\end{tabular}


Dasar pengambilan keputusan dalam uji validitas dikatakan valid jika harga $r$ hitung $>r$ tabel. Sebaliknya, item dikatakan tidak valid jika harga $r$ hitung $<r$ tabel. Pengujian validitas di $r$ tabel menggunakan tingkat signifikansi 95\% dan tingkat kesalahan (a) sebesar 5\%. $\mathrm{R}$ tabel didapat dengan $\mathrm{df}=$ $\mathrm{n}$ - 2, dengan jumlah sampel sebanyak 100, maka:

$$
\mathrm{df}=\mathrm{n}-2, \mathrm{df}=100-2=98, \mathrm{r}(0,05 ; 98)=0,196
$$

\section{Uji Reliabilitas}

Suatu kuesioner dinyatakan reliabel atau handal jika jawaban seseorang terhadap pernyataan adalah konsisten atau stabil dari waktu ke waktu (Ghozali, 2014). Uji reliabilitas dilakukan untuk mengetahui apakah alat pengukuran mempunyai kehandalan dalam mengukur. Suatu konstruk atau variabel dikatakan reliabel jika memberikan nila Cronbach's Alpha > 0.60 (Ghozali, 2014).

Tabel 7 Uji Reliabilitas

\begin{tabular}{lcc}
\hline \multicolumn{1}{c}{ Variabel } & Cronbach's Alpha & Keterangan \\
\hline Sistem Pengendalian manajemen (X) & 0,760 & Reliabel \\
Kinerja Pengadilan (Y) & 0,717 & Reliabel \\
\hline
\end{tabular}

Sumber: Data Lampiran, Output Hasil SPSS, 2020.

Hasil uji reliabilitas diperoleh nilai koefisien reliabilitas kuesioner $\mathrm{X}$ sebesar 0,760, dan kuesioner Y sebesar 0,717 menunjukkan bahwa Cronbach's alpha pada semua variabel penelitian ini lebih besar dari 0,60. Maka, berdasarkan nilai koefisien reliabilitas tersebut dapat disimpulkan bahwa semua kuesioner dalam penelitian ini reliabel atau konsisten, sehingga dapat digunakan sebagai instrumen penelitian.

\section{Uji Normalitas}

Uji normalitas bertujuan untuk menguji apakah dalam model regresi, variabel pengganggu atau residual memiliki distribusi normal. Menurut Ghozali (2013) uji normalitas memiliki tujuan untuk menguji apakah di dalam model penelitian variabel terdistribusi normal atau tidak. Model regresi yang baik adalah model regresi yang nilai residualnya normal atau mendekati normal. Proses uji normalitas data dilakukan dengan memperhatikan penyebaran data (titik) pada plot of regression standardized residual dari variabel independen sebagai berikut:

Berdasarkan hasil uji normalitas P- plot of regression standardized residual menunjukkan penyebaran data yang berada di sekitar garis diagonal dan mengikuti arah garis diagonal dan hasil uji normalitas One-Sample Kolmogorov-Smirnov Test menunjukkan nilai signifikan diatas 0,05 maka data terdistribusi normal. Hasil ini menunjukkan bahwa model regresi telah memenuhi asumsi normalitas.

\section{Hasil Pengujian Hipotesis \\ Hasil Pengujian Model}

Uji F digunakan untuk menguji variabel bebas secara bersama-sama mempunyai pengaruh yang signifikan atau tidak terhadap variabel terikat. Pengujian ini dilakukan dengan uji $\mathrm{F}$ pada tingkat kepercayaan $95 \%$ atau $\alpha 0,05$. Berikut adalah hasil pengujian uji statistik F dalam penelitian ini

Tabel 8 Hasil Pengujian Model

\begin{tabular}{|c|c|c|c|c|c|c|}
\hline \multicolumn{7}{|c|}{ ANOVA $^{a}$} \\
\hline \multicolumn{2}{|l|}{ Model } & $\begin{array}{c}\text { Sum of } \\
\text { Squares }\end{array}$ & Df & $\begin{array}{l}\text { Mean } \\
\text { Square }\end{array}$ & $\mathrm{F}$ & \\
\hline \multirow[t]{3}{*}{1} & Regression & 255,613 & 1 & 255,613 & 265,396 &, $000^{\mathrm{b}}$ \\
\hline & Residual & 94,388 & 98 & 963 & & \\
\hline & Total & 350,000 & 99 & & & \\
\hline $\begin{array}{l}\text { a. Depe } \\
\text { b. Predi }\end{array}$ & $\begin{array}{l}\text { dent Variable: } \\
\text { tors: (Constant }\end{array}$ & & & & & \\
\hline
\end{tabular}

Sumber: SPSS Versi 26 for Windows. 
Berdasarkan hasil pada tabel di atas dapat dilihat bahwa $\mathrm{F}$ hitung $=265,396>\mathrm{F}$ tabel $=3,94$ dengan nilai signifikan sebesar $0,000<0,05$ yang menunjukkan bahwa sistem pengendalian manajemen mempunyai pengaruh yang signifikan terhadap kinerja Pengadilan Negeri Tanjung Karang kelas IA. Berdasarkan hasil di atas dapat disimpulkan bahwa sistem pengendalian manajemen mempunyai pengaruh yang positif dan signifikan terhadap kinerja Pengadilan Negeri Tanjung Karang kelas IA di masa wabah Covid-19.

\section{Hasil Pengujian Koefisien Regresi}

Pengujian ini bertujuan untuk mengetahui ada atau tidaknya pengaruh terpisah dari masing- masing variabel bebas terhadap variabel terikat dengan menggunakan uji t pada tingkat kepercayaan 95\% $(\alpha=$ $0,05 \%)$ dengan derajat kebebasan $(\mathrm{dk})=\mathrm{n}-\mathrm{k}-\mathrm{l}$.

Tabel 9 Hasil Pengujian Koefisien Regresi

\begin{tabular}{|c|c|c|c|c|c|c|}
\hline \multicolumn{7}{|c|}{ Coefficients } \\
\hline \multirow[t]{2}{*}{ Model } & & \multicolumn{2}{|c|}{ Unstandardized Coefficients } & $\begin{array}{r}\text { Standardized } \\
\text { Coefficients }\end{array}$ & $\mathrm{t}$ & Sig. \\
\hline & & B & Std. Error & Beta & & \\
\hline 1 & (Constant) &, 750 & 1,320 & &, 568 &, 571 \\
\hline a. Depe & $\begin{array}{l}\text { SPM } \\
\text { nt Variable: Kinerja }\end{array}$ & ,596 &, 037 &, 855 & 16,291 &, 000 \\
\hline
\end{tabular}

Sumber: SPSS Versi 26 for Windows.

Berdasarkan hasil uji statistik dan persamaan regresi di atas maka dapat dijelaskan sebagai berikut:

1. Nilai konstanta adalah nilai yang bersifat tidak bisa diubah atau ditetapkan. Nilai konstanta sebesar 0,750 artinya jika variabel sistem pengendalian manajemen nilainya adalah 0 maka Kinerja Pengadilan (Y) nilainya akan tetap 0,750. Nilai konstanta tidak mempengaruhi variabel lainnya.

2. Berdasarkan tabel 4.16 tingkat signifikansi variabel Sistem Pengendalian Manajemen (X) yaitu sebesar 0,000 (nilai signifikansi > 0,05). Hal ini menunjukkan bahwa variabel sistem pengendalian manajemen berpengaruh signifikan terhadap Kinerja Pengadilan Negeri Tanjung Karang kelas IA di masa wabah Covid-19. Berdasarkan persamaan regresi diketahui bahwa nilai koefisien variabel Sistem Pengendalian Manajemen (X) yaitu sebesar 0,596 bernilai positif, sehingga hal ini membuktikan bahwa sistem pengendalian manajemen berpengaruh terhadap kinerja Pengadilan Negeri Tanjung Karang di masa wabah Covid-19. Dengan demikian hipotesis yang menyatakan "Sistem pengendalian manajemen berpengaruh positif terhadap kinerja pengadilan negeri tanjung karang” terdukung.

\section{Hasil Pengujian Koefisien Determinasi (Adjusted $\mathbf{R}^{\mathbf{2}}$ )}

Koefisien determinasi (Adjusted $R^{2}$ ) dilakukan untuk mengukur seberapa jauh kemampuan model dalam menerangkan variasi variabel dependen. Dengan kata lain, koefisien determinasi ini digunakan untuk mengukur seberapa jauh variabel-variabel bebas dalam menerangkan variabel terikatnya. Berikut hasil perhitungan dan output dari koefisien (Adjusted $R^{2}$ ):

\section{Tabel 10 Hasil Uji Koefisien Determinasi (Adjusted $\boldsymbol{R}^{2}$ )}

\begin{tabular}{|c|c|c|c|c|}
\hline \multicolumn{5}{|c|}{ Model Summary } \\
\hline $\begin{array}{l}\text { Mode } \\
1\end{array}$ & $\mathrm{R}$ & $R_{\text {Square }}$ & $\begin{array}{l}\text { Adjusted R } \\
\text { Square }\end{array}$ & $\begin{array}{l}\text { Std. Error of } \\
\text { the Estimate }\end{array}$ \\
\hline 1 &, $855^{\mathrm{a}}$ &, 730 & ,728 & ,981 \\
\hline a. Pred & (Const: & t), SPM & & \\
\hline
\end{tabular}

Sumber: SPSS Versi 26 for Windows.

Berdasarkan output diatas, menunjukkan nilai koefisien determinasi (adjusted $R^{2}$ ) sebesar 0,728 yang artinya pengaruh variabel Sistem Pengendalian Manajemen (X) terhadap variabel Kinerja Pengadilan (Y) sebesar 72,8\%. Sisanya dipengaruhi oleh variabel-variabel di luar variabel dalam penelitian ini. Berdasarkan hasil pengujian hipotesis dapat diketahui sistem pengendalian manajemen menunjukkan arah positif dengan nilai koefisien beta sebesar 0,596 dan nilai signifikansi sebesar $0,00<0,05$ sehingga dapat 
disimpulkan bahwa variabel independen sistem pengendalian manajemen berpengaruh positif signifikan terhadap kinerja Pengadilan Negeri Tanjung Karang kelas IA di masa wabah Covid-19.

Penelitian ini konsisten dengan penelitian yang dilakukan Gani Abdel Majed (2013) dan Rofikotul Arfati (2017) yang menyatakan Sistem Pengendalian Manajemen berpengaruh positif terhadap kinerja organisasi dan memiliki peran besar bagi peningkatan kinerja organisasi.

\section{E. SIMPULAN DAN SARAN}

Hasil penelitian ini memberikan bukti empiris bahwa Sistem Pengendalian Manajemen berpengaruh signifikan positif terhadap Kinerja Pengadilan di masa wabah Covid-19. Hal ini dikarenakan sistem pengendalian manajemen yang diterapkan di Pengadilan Negeri Tanjung Karang kelas IA telah beradaptasi dengan kondisi pandemi Covid-19 dan terbukti efektif sehingga pegawai di Pengadilan memiliki pedoman yang jelas yang kemudian dapat meningkatkan kinerja pegawai Pengadilan Negeri Tanjung Karang kelas IA.

\section{Limitasi dan studi lanjutan}

Penelitian ini tidak mampu mengontrol sepenuhnya kesungguhan dan kejujuran responden dalam menjawab dikarenakan Pengadilan Negeri Tanjung Karang Kelas IA telah menerapkan pelayanan terpadu satu pintu (PTSP) sehingga peneliti terbatas untuk mendistribusikan secara langsung lembar kuesioner kepada responden melainkan menitipkan lembar kuesioner kepada petugas yang berwenang untuk kemudian didistribusikan kepada seluruh responden dan pada penelitian ini kuesioner yang disusun terdapat beberapa poin pernyataan pada kuesioner yang tidak tepat sasaran dan berpotensi mengurangi kualitas data yang diperoleh.

Berdasarkan hasil penelitian yang telah dilakukan, saran yang diberikan peneliti adalah sebagai berikut:

1. Bagi pembaca, hasil penelitian ini diharapkan dapat menjadi inspirasi dalam membuat tulisantulisan dan menambah wawasan yang berkaitan dengan sistem pengendalian manajemen dan kinerja organisasi sektor publik.

2. Bagi peneliti selanjutnya, khususnya yang tertarik untuk mengetahui lebih jauh mengenai kinerja organisasi sektor publik (melakukan penelitian) maka perlu modifikasi variabel- variabel independen baik menambahkan variabel atau memperluas wilayah objek penelitian, sehingga lebih objektif dan bervariasi dalam melakukan penelitian.

\section{REFERENSI}

Gani Abdel Majid. 2013. Pengaruh Sistem Pengendalian Manajemen dan Implementasi Manajemen Kualitas Terhadap Kinerja Perusahaan (Studi Empiris pada Perusahaan Konstruksi di Kota Padang). Fakultas Ekonomi Universitas Negeri Padang Indonesia.

Ghozali, Imam. 2013. Aplikasi Analisis Multivariate dengan Program IBM SPSS. Edisi 7. Semarang: Penerbit Universitas Diponegoro.

Ghozali, 2014. Aplikasi analisis Multivariate dengan Program SPSS. Badan Penerbit UNDIP, Semarang.

Ghozali. (2016). Aplikasi Analisis Multivariete Dengan Program IBM SPSS. Semarang: Badan Penerbit Universitas Diponegoro.

Hartono, Jogiyanto. (2007). Metodologi Penelitian Bisnis: Salah Kaprah dan Pengalaman- Pengalaman. Edisi 2007. BPFE. Yogyakarta.

Herujito Yayat M.. 2006. Dasar-Dasar Manajemen. Jakarta: PT Grasindo.

Koesmono H. Teman, 2005. Pengaruh Budaya Organisasi terhadap Motivasi dan Kepuasan Kerja serta Kinerja Karyawan pada Sub Sektor Industri Pengolahan Kayu Ekspor di Jawa Timur, Disertasi Universitas Airlangga, Surabaya.

Renyowijoyo, Muindro. 2012. Akuntansi Sektor Publik. Jakarta : Mitra Wacana Media

Rofikotul Arfati. 2017. Pengaruh Manajemen Pengetahuan, Budaya Organisasi terhadap Kinerja Organisasi. Jurnal 
Akuntansi Universitas Jember.

Peljhan, D., Tekavcic, M. 2008. The Impact of Management Control Systems - Strategy Interaction on Performance Management: A Case Study, 41(5), 174- 184.

Sumarsan, Thomas. 2013. Sistem Pengendalian Manajemen, Konsep, Aplikasi dan Pengukuran Kinerja. Edisi 2. Indeks.

Verbeeten, Frank H.M. 2007. Performance management practices in public sector organizations impact on performance. Rotterdam School of Management, Erasmus University, Rotterdam, The Netherlands.

Widodo, Edi Supriyadi. 2014. Praperadilan di Indonesia: Teori, Sejarah, dan Praktiknya. Jakarta: Institute for Criminal Justice Reform. 